\title{
Factors Affecting Entrepreneurial Attitude: Experience from Graduating Students of Addis Ababa Science and Technology University
}

\author{
Wallelign Wondie Abebe, Reta Megersa Hundie, and Geremew Teklu Tsigu
}

\begin{abstract}
Studies and literature reveal that students' attitude to create their own business is influenced by different endogenous and exogenous factors. The study aimed at analyzing factors affecting students' entrepreneurial attitude. The factors considered in this study are family background, role model and entrepreneurial government support programs. Explanatory design was employed to check the magnitude of cause and effect relationship. 328 questionnaires were distributed sampled respondents and intensive interview was conducted with key informants. Key results of the study imply that the explanatory factors identified above positively and significantly affect the dependent variable. The family background, government entrepreneurial support programs and role model combined and explained $79.7 \%$ of the variation in entrepreneurial attitude of the students. Thus, if the government and/or the university can devise strategy upon these variables, there is a promising possibility that the attitude of the students for creating their own job.
\end{abstract}

Index Terms - Entrepreneurial attitude, Family background, Role model, Government entrepreneurial support and Addis Ababa Science and Technology University.

\section{INTRODUCTION ${ }^{1}$}

It has been widely acknowledged that entrepreneurship plays a key role in boosting economic prosperity, social welfare, and personal development [1], [2]. Ethiopia is a country whose economy needs a young that create job in its own and generate income. Developing economy like that of Ethiopia needs young that has the right attitude to generate its own income. Entrepreneurial attitude is one among many drivers of job creation and economic growth. Students commonly seek for employment after their graduation.

For the past three four decades, unemployment rate has been mounting in Ethiopia. The current Covid-19 pandemic has aggravated the unemployment problem in the country.

These unemployed young have become a big challenge for the authorities in economic and social regards. The increasing unemployment has caused political instability in addition to the socioeconomic problems in the country. Self-employment, therefore, can contribute a great amount to the endeavors of the authorities to alleviate such multifaceted national problems [3]-[7].

\section{Published on December 30, 2020.}

Wallelign Wondie Abebe, Business and Management Department, Addis Ababa Science and Technology University, Ethiopia.

(corresponding e-mail: wallelign.wondie@ ${ }^{@}$ aastu.edu.et )

Reta Megersa Hundie, Business and Management Department, Addis Ababa Science and Technology University, Ethiopia.

(e-mail: reta.megersa ${ }^{\circledR}$ aastu.edu.et)

Geremew Teklu Tsigu, Business and Management Department, Addis Ababa Science and Technology University, Ethiopia.

(e-mail: geremew.teklu@aastu.edu.et)
[8] States that entrepreneurial attitude is a function of various factors such as personality traits, education, experience, social and economic conditions, and family background among other related indicators.

This study, has tried to figure out which factor better predicts students entrepreneurial attitude.

\section{A. Objectives of the Study}

1. To analyze the level of practice of the students' entrepreneurial attitude as dependent variable and family background, role model, government entrepreneurial support, business ecosystem and university wide entrepreneurial support.

2. To analysis the magnitude of association that exist among the study variable.

3. To find out the magnitude of percentage change explained in students' entrepreneurial attitude by the study model.

\section{LITERATURE REVIEW}

Entrepreneurship development programs is characterized as a collection of formalized teachings that informs, trains, and educates anyone interested in participating in socioeconomic development through a project to promote entrepreneurship awareness, business creation, and small business development, or to train the trainers [9].

Entrepreneurship is a process by which an individual recognizes an opportunity through the method of considering both controllable and uncontrollable resources [10]. Within entrepreneurship lies the core concept of the identification of opportunities and bringing new ideas to life [11]. This can be achieved by an individual or a group of individuals, as long as they possess creativity, passion, and a risk-taking mindset.

Starting up a venture is a complex process calling for accumulating necessary resources before entrepreneurial activities is initiated [12]. [13] noted that the social capital provides considerable resources if leveraged adequately for nascent entrepreneurs. For example, the emotional and financial support from family and friends is critical in entrepreneurial process [14]. [15] also argued that role models provide learning, inspiration, motivation, and help individuals to form self-concept, when they are appraised as credible, trustworthiness, expert, and prestigious individuals [16]. States if there is identification with the role model, modeling can be 'one of the most powerful ways of transmitting values, attitudes and models of reflection and action'.

Entrepreneurial attitude is considered to be one of the most important factors influencing students' intention and 
success in becoming entrepreneurs. Many people say that attitude matters. It influences a person to behave in a certain way. In fact the behavior of a person is a reflection of the attitude of the person and who the person is. Therefore entrepreneurs who want to see themselves at the top must take time to work on their attitude. Attitude is assumed to be a better explanatory factor for a career choice than demographic variables [17]. They argue that attitude influences confidence, enthusiasm, inclination and aspiration toward entrepreneurship.

Entrepreneurial attitude is better expressed as an individual feelings, thought and conations toward selfemployment. It is considered as a function of value, belief and favorability of one's imbedded mental process [18].

On a survey conducted on Nigerian undergraduate students, they identified that specialized and practical education directed towards entrepreneurship has a significant influence in motivating students to become entrepreneurs [19].

An attitude is a mental neural state of readiness, organized through experience exerting a directive or dynamic influence upon the individual's response to all objects and situations with which it is related. Therefore, there is a strong ascertaining that attitude plays a very important role in determining the learning behaviors of students in Universities. This called for a continued effort by the researchers to make sure that students develop a positive entrepreneurial attitude [20].

According to [21], items such as attitudes, subjective beliefs, and perceived behavioral restrictions became essential factors for explaining entrepreneurial attitude [22].

In a same fashion [23], explain that there is a strong correlation between family background and participation in entrepreneurial activity. The common premise is that a good influence brought by family about entrepreneurship who contribute to higher entrepreneurial tendency to startup business. Other Study also conducted across countries between Italian and Argentinean among undergraduate students and the study found that entrepreneurial family background has a bigger impact on the propensity towards starting one's own business [24].

\begin{tabular}{|l|l|}
\hline $\begin{array}{l}\text { Family background (FB) } \\
\text { Role model (RM) } \\
\text { Government entrepreneurial } \\
\text { support program (GES) } \\
\text { Business ecosystem (BES) wide } \\
\begin{array}{l}\text { University } \\
\text { entrepreneurial support (UES) }\end{array}\end{array} \quad \begin{array}{l}\text { Students' } \\
\text { entrepreneuri } \\
\text { al attitude } \\
\text { (Att) }\end{array}$ \\
\hline
\end{tabular}

Fig. 1. The Conceptual Framework of the Study. Source: Derived from the reviews literature, 2020

\section{RESEARCH METHODOLOGY}

The study applied an explanatory research design to explain the magnitude of the relationship among the study variables. It employed an existing theoretical relationship thus is deductive by approach. Primary data was collected through structured questionnaire from a 312 randomized graduating class students and interview was conducted with three officials concerned. This helped to triangulate the finding from both sources. The collected data was analyzed with the help of inferential statistics: product moment correlation and simultaneous multiple linear regression techniques.

Thus,

$\mathrm{Y}($ attitude $)=\mathrm{a}+\mathrm{b} 1($ family $)+\mathrm{b} 2($ Role model $)+$ b3(Government support) + b4 (Business ecosystem $)+$ b5(University entrepreneurial support) $+\mathcal{E}$.

Legend: A
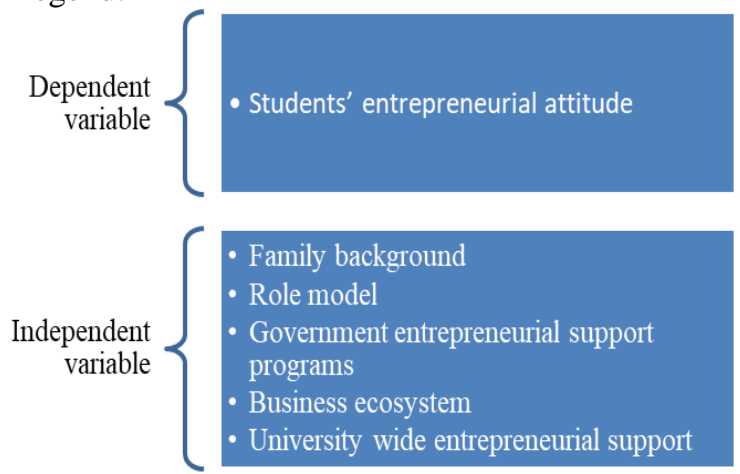

Validity of the instrument was tasted through intensive literature review, incorporating expert critique and pilot testing. Reliability of the instrument was checked by calculating Cronbach Alpha scores.

\begin{tabular}{ccc}
\multicolumn{3}{c}{ TABLE 1: RELIABILITY SCORES } \\
\hline Variables & No. of Item & Alpha Score \\
\hline Att & 5 & .66 \\
FB & 5 & .62 \\
RM & 5 & .72 \\
GES & 5 & .72 \\
BES & 5 & .70 \\
UES & 6 & .72 \\
\hline
\end{tabular}

Source: Own data: 2020 .

The finding reveals that the alpha scores satisfy the minimum requirement for further analysis.

\section{RESUlt AND DisCUSSION}

A. Descriptive Characteristic of the Study Variables

TABLE 2: DESCRIPTIVE EXPRESSION OF STUDY VARIABLES, N=312

\begin{tabular}{cccc}
\hline No & Variable & Mean & STD \\
\hline 1 & Attitude & 3.97 & 0.52 \\
2 & Family & 3.28 & 0.70 \\
3 & Role Model & 3.70 & 0.59 \\
4 & Government Support & 3.50 & 0.77 \\
5 & Business Ecosystem & 3.35 & 0.70 \\
6 & University Support & 3.60 & 0.65 \\
\hline Own survey, 2020.
\end{tabular}

Source: Own survey, 2020.

The table above shows that the level of the presence of the study variables is notable that further statistical analysis can be carried out.

\section{B. Relationship Investigation of the Study Variables}

1) Analysis of association among the variables TABLE 3: ASSOCIATION ANALYSIS AMONG STUDY VARIABLES; N=312

\begin{tabular}{cccccccc}
\hline No & Var. & 1 & 2 & 3 & 4 & 5 & 6 \\
\hline 1 & Att & 1 & & & & & \\
2 & Fam & $.88^{* *}$ & 1 & & & & \\
3 & RM & $.70^{* *}$ & $.74^{* *}$ & 1 & & & \\
4 & GS & $.76^{* *}$ & $.76^{* *}$ & $.67^{* *}$ & 1 & & \\
5 & BES & $.57^{* *}$ & $.71^{* *}$ & $.66^{* *}$ & $.71^{* *}$ & 1 & \\
6 & UES & $.59^{* *}$ & $.63^{* *}$ & $.59^{* *}$ & $.73^{* *}$ & $.89^{* *}$ & 1 \\
\hline
\end{tabular}

Note: ${ }^{* *}$ Correlation is significant at 0.01 level (2- tailed).

Source: Own survey, 2020. 
Correlation technique is used to answer three questions about the variables: 'Is there a relationship between the variables? What is the direction of the relationship? And what is the magnitude?

The score computed above shows that there is strong positive association among the study variables. [25] as cited by [26], suggests that, correlation score between 0.10 to 0.29 depicts weak association, correlation score between 0.30 to 0.49 depicts medium association, and correlation score between 0.50 up to 1.0 depicts strong association ranges among study variables. This finding implies that there exists strong positive association among students' entrepreneurial attitude, family, Role model, government entrepreneurial support, business ecosystem and university entrepreneurial support. This finding, in turn, warrants that causation analysis can be computed.

2) Analysis the Magnitude of Causation

TABLE 4: Simultaneous Multiple REgResSion ANALYSIS Summary

\begin{tabular}{cccc}
\multicolumn{4}{c}{$(\mathrm{N}=312)$} \\
\hline Variables & $\mathrm{B}$ & SEB & $\mathrm{B}$ \\
\hline Fm & .623 & .03 & .11 \\
RM & .099 & .03 & .82 \\
GES & .116 & .03 & .17 \\
BE & -.377 & .04 & -.50 \\
UES & .265 & .04 & .33 \\
Constant & 1.47 & .08 & \\
\hline Note: $\mathrm{R}^{2}=.838 ; \mathrm{F}(5,306)=317.125 ; \mathrm{P}<0.01$
\end{tabular}

Source: Own survey, 2020.

Simultaneous multiple regression was conducted to investigate the best predictor of entrepreneurial attitude of graduating students score. The combination of family background, the effect of role model, government entrepreneurial support programs, business ecosystem, and university wide entrepreneurial support was calculated, $\mathrm{F}(5,306)=317.125 ; \mathrm{P}<0.01$. This score imply that all the variables considered significantly predicted entrepreneurial attitude. The adjusted $\mathrm{R}^{2}$ was 0.838 ; this indicates that $83.8 \%$ percent of the variation in entrepreneurial attitude is explained by the model. According to [25], this is a large effect. The possibility for the students' entrepreneurial attitude to improve is high if strategy is devised to enhance the constructs of the study.

What the researcher wanted to identify was that which of the explanatory variables included in the model is/are contribute more to the prediction of the student's entrepreneurial attitude. The largest beta coefficient is scored by family background. $(B=0.623)$. This means that family background made the strongest contribution in explaining students' entrepreneurial attitude.

On the other hand, as per [26], squaring the beta value and multiplying by 100 shows the unique/significant contributions of each independent variable. Accordingly, the beta value of the effect of family background 0.623 and by making it square we get 0.388129 . It means that the contribution of family background to entrepreneurial attitude $38.8 \%$ and by a similar calculation, the unique contribution of government entrepreneurial supporting programs is $1.35 \%$ while university wide entrepreneurial supports is $7 \%$. This might imply that working on these variables can bring a success in venture formation.

Therefore, from all explanatory variables, family background, followed by university wide entrepreneurial support, has the strongest unique contribution to entrepreneurial attitude formation in the study area.

The confirmed model is expressed as:

$$
Y=\beta 0+\beta 1 \chi 1+\beta 2 \chi^{2}+\beta 3 \chi^{3}+\beta 4 \chi 4+e
$$

where:

$\mathrm{Y}=$ Entrepreneurial attitude;

$\chi 1=$ Family background;

$\chi 2=$ Role model;

$\chi 3=$ Government entrepreneurial support programs;

$\chi 4=$ Business ecosystem;

$\chi 5=$ University wide entrepreneurial support;

$\beta 0=$ the constant;

$\beta 1-\mathrm{n}=$ the regression coefficient or change included in $\mathrm{Y}$ by each $\chi$;

$\epsilon=$ standard error term.

Thus, according to the finding:

Attitude $=1.47+0.62($ Family $)+0.10($ Role Model $)+$ 0.12 (Government Support) + -0.38(Business ecosystem $)+$ 0.27 (University support) +0.21

\section{CONCLUSION}

This study has provided an empirical justification for the conceptual framework that identified five explanatory constructs that considered family background, role model, government entrepreneurial support programs, business ecosystem and university wide entrepreneurial support. Strong statistical association was observed among the constructs within the context of the study area. In addition, the causation analysis reported that the model strongly explained the variance in students' entrepreneurial attitude. From the proposed constructs, the role of family background was higher than the others. Therefore, if a policy frame work is enacted to enhance the business understanding and engagement of the family members, there is high possibility that students' entrepreneurial attitude improves. The second was university wide entrepreneurial support and government entrepreneurial support. This in turn, might significantly contribute to start up proliferation required to create jobs and thus boost the economy. The other important finding of this study is that the university wide entrepreneurial support provided to students significantly predict students' entrepreneurial attitude.

Thus, the university is required to enhance its entrepreneurial support to graduating student by means of short term training, course work and enhancing the business incubation center.

\section{ACKNOWLEDGMENT}

We dearly express our sincere gratitude to all those who contributed towards the completion of this work. To those who sacrificed their precious time in completing the data collection instrument, to the university management who permitted the research. Mr.Gessesse kebede, Mr. Ashenafi Taye, Mr. Areda Batu, Mr. Gudeta Gelashe, all deserve 
heartfelt applaud for their unreserved support in collecting and managing the data.

\section{REFERENCES}

[1] Fauziah SA, Rohaizat B \& Siti Haslinah AR Interest in entrepreneurship: An exploratory study on engineering and technical student in entrepreneurship education and choosing entrepreneur as a career. 2004.

[2] R. Hisrich and M. Peters, Entrepreneurship, 6th ed., Boston: McGraw-Hill/Irwin, 2005.

[3] Robinson, P., \& Haynes, M. Entrepreneurship education in America's major universities. Entrepreneurship Theory and Practice, 15(3), 41-52. 1991

[4] Ammal, A., \& Mathi, K. Attitudes of Undergraduate Student towards Entrepreneurship as a career choice in Oman. Journal of international academic research for multidisciplinary,2(6), 651-661. 2014.

[5] Koh, H. C. Factors associated with entrepreneurial inclination: an empirical study of business undergraduates in Hong Kong. Journal of Small Business and Entrepreneurship, 12(2), 29-41. 1995.

[6] Koh, H. C. Factors associated with entrepreneurial inclination: an empirical study of business undergraduates in Hong Kong. Journal of Small Business and Entrepreneurship, 12(2), 29-41. 1995.

[7] Koh, W. T. H., \& Wong, P. K. Competing at the frontier: the changing role of technology policy in Singapore's economic strategy. Technological Forecasting and Social Change, 72(1), 255285. Elsevier. 2005.

[8] aramond, S. Attitude towards entrepreneurship in organization. The Journal of Entrepreneurship, 13(1), 53-68. 2004.

[9] Tan, W.L., Long, A., \& Robinson, P. Entrepreneurship attitude orientation and the intentionto starta business. Journal of Small Business Management, 13(4), 50-61. 1996.

[10] Tkachev, A., \& Kolvereid, L. Self-employment intentions among Russian students. Entrepreneurship and Regional Development, 11(1), 269-280. 1999.

[11] Berchand JP \& Toulouse JM. Validation of a didactic model for the analysis of training objectives in entrepreneurship. Journal of Business Venturing; 13(4):317-312. 1998.

[12] Bygrave, W. D., \& Zacharakis, A. Entrepreneurship (2nd ed. ed.): Wiley2011.

[13] Burns, P. New venture creation: Aframe work for entrepreneurial start-ups: Palgrave Macmillan. 2014.

[14] Schumpeter, J. A. The Theory of Economic Development: An Inquiry into Profits, Capital, Credit, Interest, and the Business Cycle. Translated by Redovers Opie. Harvard University Press. 1961.

[15] Leff, N. H. Entrepreneurship and economic development: The problem revisited. Journal of economic literature. 17(1): 46-641979.

[16] Yang, J. H. A study on the effect of contextual factors on entrepreneurial intention of Korean university students. Korean Business Education Review. 30(1): 25-45. 2015.

[17] Yang, J. H. Effect of perceived relational supports on entrepreneurial motivation of Korean and Chinese university students: Focused on mediating role of self-efficacy. Asia-Pacific Journal of Business Venturing and Entrepreneurship. 10(3): 1-13. 2015.

[18] Yang, J. H. The effect of role model and entrepreneurship education on entrepreneurial intention of Korean juvenile. Asia-Pacific Journal of Business Venturing and Entrepreneurship. 12(2): 69-81. 2017.

[19] Yang, J. H., D. Y. Chung and C. K. Kim. How entrepreneurial role model effects on entrepreneurial self-efficacy and entrepreneurial motivation of Korean university students?: Focused on mediating effect of entrepreneurial self-efficacy. Korean Business Education Review. 32(3): 115-135. http://dx.doi.org/10.23839/kabe.2017.32.3.115.

[20] Gibson, S.G., Harris, M.L., \& Barber III, D. (2008). An examination of entrepreneurial personality factors in a Brazilian student population. Proceedings of Southeast Annual Meeting, October 2008.

[21] Bandura, A. Social Foundation of Thought and Action-A social cognitive theory. Englewood Cliffs. New Jersey: Prentice-Hall. 1986.

[22] Robinson, P. B., D. V. Stimpson, J. C. Huefner and H. K. Hunt (1991). An Attitude Approach to The Prediction Of Agripreneurship. Agripreneurship Theory \& Practice. Summer. 15(4): $13-30$
[23] Schultz PW, Oskamp. Effort as a moderator of the attitude behaviour relationship: general environmental concern and recycling. Social Psychology Q. 1996; 59:375-383.

[24] Abraham Abebe. Attitudes of undergraduate students towards selfemployment in Ethiopian public universities. International journal of business and management review, 3(7): 1-10. 2015.

[25] Ajzen, I. The theory of planned behavior. Organization Behavior and Human Decision Processes, 50: 179-211. 1991.

[26] Oakey, R., P., Mukhtar, S. \& Kipling, M., Student Perspective on Entrepreneurship: International Journal Entrepreneurship and Innovation Management, 12 (4/5), 308- 319. 2002.

[27] Arzeni, S., \& Mitra, J. From unemployment to entrepreneurship Creating conditions for change for young People in central and eastern European countries, in Blokker, P. Dallago, B.: Youth entrepreneurship and local development in central and eastern Europe. Hampshire: Ashgate.31-60. 2008.

[28] Morrison, A. Entrepreneurship: What Triggers It? International Journal of Entrepreneurial Behave \& Research, 6(2), 59-71. 2000.

[29] Postigo, S., Lacobucci, D. \& Tamborini, M., F. Undergraduate Students as a Source of Entrepreneurs: A Comparative Study between Italy and Argentina. International Entrepreneurship Education: Issues and Newness. 2006.

[30] Cohen, L., Manion, L., \& Morrison, K. Research Methods in Education $\left(6^{\text {th }}\right.$ ed.). London and New York, NY: Routledge Falmer. 2007.

[31] Pallant, J. SPSS survival manual. McGraw-Hill Education (UK) 2013. 